\title{
ANALISIS KEMAMPUAN LITERASI MATEMATIS DAN BURNOUT BERPIKIR KREATIF PESERTA DIDIK BERDASARKAN PEMBELAJARAN MMP (SOMATIC, AUDITORY, VISUAL AND INTELLECTUALLY)
}

\author{
Nur Asiyah Jamil ${ }^{1}$, Bambang Sri Anggoro ${ }^{2}$, Wawan Gunawan ${ }^{3}$ \\ UIN Raden Intan Lampung, Jalan Endro Suratmin, Sukarame, Bandar Lampung, 1,2,3 \\ Email : Nurasiyahj03@gmail.com
}

\begin{abstract}
ABSTRAK
Penelitian ini bertujuan untuk menganalisis kemampuan literasi matematis dan burnout peserta didik berdasarkan model pembelajaran MMP (Misouri Mathematics Project). Penelitian ini merupakan penelitian jenis Quisi Experimental Design. Populasi pada penelitian ini yaitu peserta didik kelas VII SMP Negeri 2Adiluwih, pengambilan sampel menggunakan teknikCluster Random Sampling didapat sampelnya yaitu kelas VII A sebagai kelas eksperimen dengan perlakuan model pembelajaran MMP dan kelas VII D sebagai kelas kontrol dengan perlakuan pembelajaran konvensional. Analisis data yang digunakan dalam penelitian ini menggunakan uji MANOVA. Menurut hasil analisis, terdapat pengaruh positif model pembelajaran MMP terhadap kemampuan literasi matematis dan burnout peserta didik. Karena adanya model MMP ini bisa menjadikan suasana belajar jadi lebih aktif dibandingkan dengan pembelajaran konvensional. Maka dapat disimpulkan bahwa terdapat pengaruh positif model MMP terhadap kemampuan literasi matematis dan burnout peserta didik.
\end{abstract}

Kata Kunci: Burnout; Literasi Matematis; MMP (Misouri Mathematics Project)

\begin{abstract}
This study aims to analyze the mathematical literacy skills and burnout of students based on the MMP (Misouri Mathematics Project). This research is a type of research Quisi Experimental Design. The population in this study were students of class VII SMP Negeri 2 Adiluwih, sampling using the technique Cluster Random Sampling obtained the sample, namely class VII A as an experimental class with MMP learning model treatment and class VII D as a control class with conventional learning treatment. Analysis of the data used in this study using the MANOVA test. According to the results of the analysis, there is a positive influence of the MMP learning model on the mathematical literacy ability and burnout of students. Because the MMP model can make the learning atmosphere more active than conventional learning. So it can be concluded that there is a positive influence of the MMP model on mathematical literacy skills and burnout of students.
\end{abstract}

Keywords: Burnout; Mathematical Literacy; MMP (Misouri Mathematics Project)

\section{PENDAHULUAN}

Pendidikan merupakan sutu proses jangka panjang yang sudah menjadi bagian yang tidak terpisahkan dalam kehidupan didunia. Pendidikan matematika adalah dasar keilmuan wajib yang menjadi dasar perkembangan ilmu pengetahuan dan teknologi. Kemampuan dalam pemecahan

141

Nur Asiyah Jamil, Bambang Sri Anggoro, Wawan Gunawan 


\section{$\pi$ (Phi)}

masalah, membangun nalar kritis yang sistematis dan kreatif yang di ajarkan pada ilmu matematika yang menjadi modal utama untuk menguasai ilmu pengetahuan dan teknologi.

Pendidikan dilaksanakan tertata dan terancang guna mewujudkan suasana belajar menjadi aktif dalam mengembangkan potensi peserta didik. Melalui pendidikan peserta didik dapat memperluas wawasannya dan memperoleh ilmu pengetahuan yang dibutuhkan(Tama dkk., n.d.). Ilmu matematika merupakan salah satu bidang ilmu pendidikan yang berperan dalam kehidupan sehari-hari dan dapat mengembangkan sumber daya manusia yang berkualitas. Matematika sebagai aktivitas manusia yang berarti manusia diberi kesempatan untuk menemukan kembali ide dan konsep matematika dengan bimbingan yang lebih dewasa(Nurussilmah dkk., n.d.). Sistem pendidikan nasional sesuai yang di tuliskan pada undang-undang Nomor 20 tahun 2003, pasal 3 menjelaskan tentang tujuan pendidikan yaitu untuk mengembangkan potensi peserta didik supaya menjdai manusia yang beriman serta bertakwa Kepada Tuhan yang Maha Esa, berakhlak mulia, sehat, berilmu, kreatif, cakap, bertanggung jawab, mandiri dan menjadi warga negara demokratis(Sistem Pendidikan Nasional, 2003).

Berdasarkanhasil wawancara yang dilakukan peneliti saat pra-penelitian

dengan pendidik di SMP Negeri2 Adiluwih, pembelajaran matematika masih menggunakan model konvensional dengan metode ceramah dan penugasan yang dibantu buku cetak sehingga masih ditemukan permasalahan peserta didik yang cepat merasa bosan terlebih materi pelajaran yang terkadang terkesan rumit membuat kebanyakan peserta didik menjadi malas mengikuti pembelajaran dan cenderung mengalami burnout. Kebanyakan peserta didik menyelesaikan masalah dengan menghafal rumus namun kesulitan ketika menerapkan dan menafsirkan rumus tersebut dalam konteks masalah matematis. Masih banyak peserta didik yang mengalami kesulitan dalam menyelesaikan masalah ketika diberikan soal yang sedikit berbeda dari contoh soal yang sudah dijelaskan sebelumnya salah satunya pada materi perbandingan.

Berdasakan hal tersebut menunjukkan bahwa kendala yang dialami peserta didik SMP Negeri 2Adiluwih dalam proses pembelajaran yaitu kemampuan literasi matematis masih tergolong rendah dan burnout yang dialami peserta didik masih cukup tinggi. Hal ini selaras dengan hasil yang diperoleh peneliti ketika memberikan tes kemampuan literasi matematis dan burnout.

Seperti yang terlihat pada tabel berikut data nilai ulangan harian peserta didik kelas VII SMP Negeri 2 Adiluwih. 
Tabel 1.Daftar Nilai Ulangan Harian Peserta Didik Kelas VIISMP Negeri 1 AdiluwihTahun Pelajaran 2019/2020

\begin{tabular}{|c|c|c|c|c|}
\hline \multirow{2}{*}{ No } & \multirow{2}{*}{ Kelas } & \multicolumn{2}{|c|}{ Interval Nilai } & \multirow{2}{*}{ Jumlah Peserta Didik } \\
\hline & & $X<75$ & $X \geq 75$ & \\
\hline 1 & VII A & 25 & 5 & 30 \\
\hline 2 & VII B & 23 & 9 & 32 \\
\hline 3 & VII C & 24 & 8 & 32 \\
\hline 4 & VII D & 23 & 7 & 30 \\
\hline 5 & VII E & 26 & 6 & 32 \\
\hline
\end{tabular}

*)sumber data: buku nilai guru

Melihat dari permasalahan diatas mengindikasikan bahwa kemampuan literasi matematis pada umumnya masih tergolong rendah dan burnout peserta didik pada umumnya masih cukup tinggi. Maka diperlukannya penerapan model pembelajaran yang tepat agar peserta didik menjadi lebih aktif dan memiliki motivasi belajar juga mengembangkan kreativitas peserta didik dalam menyelesaikan masalah dengan konsepnya sendiri dari materi yang telah dijelaskan pendidik.

Model pembelajaran missoury mathematics project (MMP) Menurut krismanto dalam Anna Fauziah Sukasno, suatu model pembelajaran yang didesain supaya pendidik dapat memaksimalkan efektivitas penggunaan latihan-latihan agar peserta didik dapat mencapai hasil yang maksimal. Sedangkan menurut Krismanto model pembelajaran MMP adalah model pembelajaran yang sistematis seperti halnya struktur pengajaran matematika. Model pembelajaran MMP memberikan kesempatan kepada peserta didik untuk belajar secara kooperatif dalam latihan dengan bimbingan pendidik kemudian peserta didik menerapkan pemahaman yang di miliki dalam setwork(Fauziah dkk., n.d.). Model pembelajaran MMP lebih memusatkan pada penugasan atau pengerjaan tugas dalam bentuk LKS kepada siswa dilihat dari seberapa paham siswa terhadap penjelasan yang sudah di jekaskan pada tahap pengembangan serta guru juga melihat cara kerja setiap siswa.

Literasi matematis merupakan salah satu domain yang diukur dalamProgramme for International Student Assessment (PISA), literasi matematis ialah kemampuan seseorang untuk merumuskan, menerapkan, dan menafsirkan matematika dalam berbagai konteks, termasuk kemampuan melakukan penalaran secara matematis dan menggunakan konsep, prosedur, fakta untuk menggambarkan, menjelaskan atau memperkirakan fenomena/kejadian, dan yang membantu seseorang untuk mengenal kegunaan matematika dalam kehidupan sehari-hari. Menurut Thomson, Hilman, \& Bortoli yang dikutip oleh Mohayat dan Netriwati, salah satu aspek penting literasi matematis ialah mampu menggunakan matematika dan bekerja secara matematis dalam berbagai situasi(B. Slivar, 2001).

Pines \& aronson mendefinisikan “ burnout may be defined as a state of physical, emotional and mental exhaustion that results from long-tern involvement that are emotionally demanding”, burnout diartikan sebagai kondisi emosional 


\section{$\pi$ (Phi)}

dimana seseorang merasa lelah dan jenuh secara mental maupun fisik sebagai akibat tuntutan pekerjaan yang meningkat(B. Slivar, 2001).Burnout merupakan salah satu gejala kejenuhan yang terjadi pada seseorang yang diakibatkan adanya tuntutan kekuatan ataupun sumber daya manusia yang berlebihan.Burnout merupakan perubahan sikap dan perilaku dalam bentuk menarik diri secara psikologis dari sesuatu hal baik pendidikan atau pekerjaan, merasa tidak berdaya, merasa tidak ada harapan, merasa terjebak kesedihan yang mendalam secara terus menerus menimbulkan rasa lelah dan ketidakberdayaan, merasa kekurangan energi untuk bekerja atau belajar, bersikap kasar terhadap orang lain dan tidak peduli dengan lingkungan sekitar.

Dari uraian diatas model pembelajaran MMP dapat digunakan dalam proses pembelajaran matematika untuk meningkatkan kemampuan literasi matematis dan burnout peserta didik. Berdasarkan penelitian (Ipa, 2014). Menyimpulkan bahwa dari penerapan model pembelajaran MMPlebih efektif dari model konvensional dan dapat meningkatkan hasil belajar peserta didik. Misouri Mathematics Project (MMP) juga melatih kerjasama antara peserta didik pada langkah kerja kooperatif, mengerjakan lembar kerja secara berkelompok akan membuat peserta didik saling membantu kesulitan masing-masing dan saling bertukar pikiran. Bagi peserta didik yang malu bertanya kepada guru jika ada kesulitan dalam memahami materi yang sedang.

\section{METODE PENELITIAN}

Metode merupakan teknis yang dilakukan dalam proses penelitian, sedangkan penelitian adalah semua kegiatan pencarian, penyelidikan, dan percobaan secara ilmiah dalam bidang tertentu untuk mendapatkan fakta-fakta yang bertujuan untuk menemukan pengertian baru dan menaikkan tingkat ilmu dan teknologi (Margono, 2004). metode penelitian adalah cara yang digunakan oleh peneliti dalam mengumpulkan data penelitiannya. Dari penjelasan tersebut peneliti menyimpulkan bahwa metode penelitian sebagai sarana yang memiliki fungsi membantu kelancaran dalam penelitian. Penelitian ini menggunakan penelitian kuantitatif dengan metode Quasi Experimental Design.

Penelitian ini menggunakan dua kelompok yang dipilih secara dengan teknik cluster random sampling, kelompok pertama sebagai kelompok eksperimen, yaitu peserta didik yang mendapat perlakuan (treatment) model pembelajaran MMP dan kelompok kedua sebagai kelompok kontrol, yaitu peserta didik yang mendapat pembelajaran konvensional. Kedua kelas diasumsikan sama dalam segi yang relevan, hanya berbeda pada perlakuan $\mathrm{X}$ yang diberikan.

Tabel 2. Desain Penelitian

\begin{tabular}{lcc}
\hline \multicolumn{1}{c}{ Kelompok } & Treatment & Post-test \\
\hline Eksperimen & $\mathrm{X}$ & $\mathrm{O}_{1}$ \\
Kontrol & - & $\mathrm{O}_{2}$ \\
\hline
\end{tabular}

Keterangan :

$\mathrm{O}_{1}=$ Post-test kemampuan literasi matematis dan Burnout kelompok eksperimen

$\mathrm{O}_{2}=$ Post-test kemampuan literasi matematis dan Burnout kelompok kontrol 
$\mathrm{X}=$ Pembelajaran menggunakan model pembelajaran MMP

Pada penelitian ini terdapat dua variabel, variabel yang memengaruhi yaitu model pembelajaran MMP (Variabel Bebas) dan variabel yang dipengaruhi adalah Kemampuan Literasi Matematis $\left(\mathrm{Y}_{1}\right)$ dan Burnout $\left(\mathrm{Y}_{2}\right)$ yang juga disebut sebagai (Variabel Terikat).

Populasi dalam penelitian ini adalah siswa kelas VIII SMP Negeri 1 Adiluwih. Terdapat beberapa teknik pengumpulan data yang digunakan yaitu tes, angket, wawancara dan dokumentasi. Instrumen penelitian yang digunakan ialah tes kemampuan literasi matematis peserta didik, serta angket burnout. Penelitian ini menggunakan uji instrumen penelitian berupa uji validitas, uji reliabilitas, uji tingkat kesukaran dan uji daya pembeda. Teknik uji hipotesis yang akan digunakan dalam penelitian ini adalah Multivariate Analysis of Varians atau yang sering didengar dengan MANOVA. Sutrisno dan Wulandari menjelaskan MANOVA merupakan teknik statistik yang digunakan untuk menghitung pengujian signifikansi perbedaan rata-rata secara bersamaan antara kelompok untuk dua variabel terikat atau lebih (Sutrisno dkk., n.d.). Adapun rumus uji MANOVA untuk membandingkan vektor mean sebanyak $g$, sebagai berikut :

$X_{i j}=\mu+\tau_{i}+e_{i j}, j=$

$1,2,3, \ldots n_{i} \operatorname{dan} I=1,2,3, \ldots, g$

Vektor observasi dapat dikomposisi ulang sesuai model, yaitu :

$$
X_{i j}=\bar{x}+\bar{x}_{i}-\bar{x}+\bar{x}_{i j}-\bar{x}_{i}
$$

Keterangan :

$X_{i j} \quad$ : observasi

$\bar{x} \quad$ : rata-rata sampel keseluruhan $\mu$

$\bar{x}_{i}+\bar{x} \quad$ : estimasi efek perlakuan $\tau_{i}$

$\bar{x}_{i j}+\bar{x}_{i}:$ residu $e_{i j}$

Hipotesis yang diujikan dapat dirumuskan sebagai berikut :

$H_{0}: \tau_{1}=\tau_{2}=\tau_{3}=\cdots=\tau_{g}$ (tidak ada

perbedaan antar perlakuan)

$H_{1}: \tau_{1} \neq \tau_{2} \neq \tau_{3} \neq \cdots \neq \tau_{g}$ (setidaknya ada perbedaan antara dua perlakuan)

\section{HASIL DAN PEMBAHASAN}

Berdasarkan data nilai kemampuan literasi matematis peserta didik, diperoleh nilai tertinggi $\left(X_{\text {maks }}\right)$, nilai terendah $\left(X_{\text {min }}\right)$, median, modus, jangkauan dan simpangan baku $(S)$ pada kelas eksperimen maupun kelas kontrol. Rangkuman hasil data amatan nilai kemampuan literasi matematis dapat dilihat pada tabel berikut :

Tabel 3. Deskripsi Data Amatan

Kemampuan Literasi Matematis Peserta Didik

\begin{tabular}{|c|c|c|c|c|c|c|c|}
\hline \multirow[t]{2}{*}{ Kelompok } & \multirow{2}{*}{$\left(X_{\text {maks }}\right)$} & \multirow{2}{*}{$\left(X_{\min }\right)$} & \multicolumn{3}{|c|}{$\begin{array}{l}\text { Ukuran Tendensi } \\
\text { Sentral }\end{array}$} & \multicolumn{2}{|c|}{$\begin{array}{l}\text { Ukuran } \\
\text { Dispersi }\end{array}$} \\
\hline & & & $\bar{X}$ & $M_{e}$ & $M_{o}$ & $R$ & $S$ \\
\hline Eksperimen & 90,63 & 56,25 & 74,2 & 76,56 & 78,13 & 34,38 & 8,079 \\
\hline Kontrol & 81,25 & 50 & 68,3 & 68,75 & 75 & 31,25 & 8,27 \\
\hline
\end{tabular}

*)sumber data: hasil penelitian 
Menurut tabel 3 dapat disimpulkan bahwa kemampuan literasi matematis peserta didik pada kelas eksperimen lebih baik dibandingkan dengan kelas kontrol dilihat dari nilai tertinggi, nilai terendah dan ukuran tendensi sentral.

Selain itu diperoleh juga data nilai Burnout peserta didik diperoleh nilai tertinggi $\left(X_{\text {maks }}\right)$, nilai terendah $\left(X_{\min }\right)$, median, modus, jangkauan dan simpangan baku $(S)$ pada kelas eksperimen maupun kelas kontrol. Rangkuman hasil data amatan nilai kemampuan literasi matematis dapat dilihat pada tabel berikut :

Tabel 4. Deskripsi Data Amatan Burnout Peserta Didik

\begin{tabular}{lccccccc}
\hline \multirow{2}{*}{ Kelompok } & \multirow{2}{*}{$\left(X_{\text {maks }}\right)$} & & \multicolumn{2}{c}{ Ukuran Tendensi } & \multicolumn{2}{c}{ Ukuran Dispersi } \\
\cline { 4 - 8 } & & & $\bar{X}$ & $M_{e}$ & $M_{o}$ & $R$ & $S$ \\
\hline Eksperimen & 83,92 & 65,17 & 75,14 & 76,78 & 69,64 & 28,57 & 6,05 \\
\hline Kontrol & 77,68 & 50,89 & 67,17 & 67,86 & 65,18 & 65,18 & 5,97 \\
\hline$*$ *)sumber data: hasil penelitian & & & & & & &
\end{tabular}

Menurut tabel 4 dapat disimpulkan bahwa kemampuan literasi matematis peserta didik pada kelas eksperimen lebih baik dibandingkan dengan kelas kontrol dilihat dari nilai tertinggi, nilai terendah dan ukuran tendensi sentral.

Sebelum melakukan uji hipotesis, terlebih dahulu dilakukan uji prasyarat hipotesis. Uji prasyarat tersebut meliputi uji normalitas dan uji homogenitas. Uji normalitas merupakan uji prasyarat yang harus dilakukan untuk mengetahui apakah populasi data berdistribusi normal atau tidak. Uji normalitas menggunakan metode Liliefors terhadap kemampuan literasi matematis dan Burnout berpikir kreatif peserta didik dengan dengan taraf signifikansi $5 \%$ dan $L_{\text {hitung }}$ untuk setiap kelas dan kemampuan memiliki nilai kurang dari $L_{\text {tabel }}(0,05)$, sehingga $H_{0}$ dapat diterima. Dapat disimpulkan bahwa data dari setiap kelompok berdistribusi normal.
Uji homogenitas dilakukan untuk mengetahui beberapa variansi populasi sama atau berbeda. Uji homogenitas ini menggunakan Uji Bartlett, dengan taraf signifikansi $5 \%$ untuk setiap $X^{2}{ }_{\text {hitung }}$ untuk setiap kemampuan memiliki nilai kurang dari $X^{2}$ tabel, sehingga $H_{0}$ diterima. Dapat disimpulkan bahwa sampel berasal dari populasi yang homogen. Setelah mengetahui bahwa data berdistribusi normal dan berasal dari populasi yang homogen maka selanjutnya adalah uji hipotesis menggunakan Uji MANOVA. Hasil perhitungan Uji MANOVA untuk hipotesis 1 dan 2 dapat disimpukan bahwa:

1) Nilai $p$-value dalam Kemampuan Literasasi Matematis (KLM) $=0,006$ dan nilai $\propto$ kriteria uji $=0,05$ yang berarti nilai $p$-value lebih kecil dibandingkan $\alpha$ kriteria uji, sehingga $H_{0 A}$ ditolak dengan demikian dapat disimpulkan bahwa terdapat pengaruh antara Model Missouri mathematics 
project terhadap kemampuan literasi matematis.

2) Nilai $p$-value dalam Burnout = 0,000 dan nilai $\propto$ kriteria uji $=0,05$ yang berarti nilai $p$-value lebih kecil dibandingkan $\alpha$ kriteria uji, sehingga $H_{0 B}$ ditolak dengan demikian dapat disimpulkan bahwa terdapat pengaruh antara model Missouri mathematics project terhadap burnout.

Setelah mengetahui uji hipotesis untuk masing-masing kemampuan, maka selanjutnya menghitung uji hipotesis untuk hipotesis ke-3. Hasil perhitungan MANOVA untuk hipotesis 3 dapat disimpukan bahwa:

Nilai dari Pillai’s Trace, Wilks’ Lambda, Hotelling's Trace, Roy's Largest Root = 0.029 dan nilai $\alpha$ kriteria uji $=0.05$ yang berarti nilai $p$-value lebih kecil dibandingkan $\alpha$ kriteria uji, sehingga $H_{0 A B}$ ditolak dengan demikian dapat disimpulkan bahwa terdapat pengaruh antara Model Missouri mathematics project terhadap kemampuan literasi matematis dan burnout.

Berdasarkan uraian diatas disimpulkan bahwa pembelajaran dengan menerapkan model MMP menghasilkan kemampuan literasi matematis dan Burnout yang lebih baik dibandingkan dengan pembelajaran konvensional. Hal itu karena pada kelas eksperimen yang menerapkan model MMP peserta didik pada langkah kerja kooperatif, mengerjakan lembar kerja secara berkelompok akan membuat peserta didik saling membantu kesulitan masing-masing dan saling bertukar pikiran.

\section{SIMPULAN}

Berdasarkan hasil penelitian dari analisis data dan pengujian hipotesis yang telah dilakukan, maka peneliti menyimpulkan bahwa ; Terdapat pengaruh antara model pembelajaran MMP (Missouri Mathematics Project) terhadap kemampuan literasi matematis peserta didik, terdapat pengaruh antara model pembelajaran MMP terhadap Burnoutpeserta didik, terdapat pengaruh antara model pembelajaran MMP terhadap kemampuan literasi matematis dan Burnout peserta didik secara simultan.

\section{DAFTAR PUSTAKA}

B. Slivar. (2001). The Syndrome of Burnout Companion to Study an Practice: Critical Analysis. CRC Press.

Fauziah, A., Journal, S. S.-I., \& 2015, undefined. (n.d.). Pengaruh Model Missouri Mathematics Project (Mmp) Terhadap Kemampuan Pemahaman Dan Pemecahan Masalah Matematika Siswa Sma NI Lubuklinggau. ejournal.stkipsiliwangi.ac.id. Diambil 13 Juni 2021, dari http://www.ejournal.stkipsiliwangi.ac.id/index.php /infinity/article/view/67

Ipa, K. (2014). Meningkatkan Kemampuan Problem Solving Mathematic Melalui Model Pembelajaran Kooperatif Tipe Missouri Mathematic Project ditinjau dari Kreativitas Peserta Didik. Pendidikan Matematika.

Margono. (2004). Metodologi Penelitian Pendidikan. PT. Rineka Cipta.

Nurussilmah, R., Santi, V., RISET, T. A.J., \& 2020, undefined. (n.d.). Pengaruh Pembelajaran SAVI (Somatic, Auditory, Visual, Intellectual) terhadap Kemampuan Pemecahan Masalah Ditinjau dari 
Tingkat Kemampuan Awal

Matematika. journal.unj.ac.id.

Diambil 13 Juni 2021, dari

http://journal.unj.ac.id/unj/index.php/j rpms/article/view/16461

Sutrisno, S., Dan, D. W.-A. J. M., \& 2018, undefined. (n.d.). Multivariate Analysis of Variance (MANOVA) untuk Memperkaya Hasil Penelitian Pendidikan. journal.upgris.ac.id. Diambil 13 Juni 2021, dari http://journal.upgris.ac.id/index.php/a ksioma/article/view/2472

Tama, A., Rinaldi, A., Jurnal, S. A.-D., \& 2018, undefined. (n.d.). Pemahaman Konsep Peserta Didik dengan Menggunakan Graded Response Models (GRM). ejournal.radenintan.ac.id. Diambil 13 Juni 2021, dari http://www.ejournal.radenintan.ac.id/i ndex.php/desimal/article/view/2041

Sistem Pendidikan Nasional, Pub. L. No. 20 (2003). 